\title{
Tourist function in rural areas of Poland. Spacial diversity and changing trends
}

\section{Abstract}

This paper presents the findings of research carried out by the author, concerning the development of tourist function in the period 1995-2005. Tourist function was defined by means of two features: the number of tourists using lodging facilities and the number of companies registered in the REGON system, section $\mathrm{H}$. In order to quantify the tourist function, a synthetic measure $\left(F_{t}\right)$ was employed according to the procedure of Z. Zioło (1973). Based on this measure, five levels of tourist function development were specified. Next, an analysis was carried out on what changes (quantitative and spatial) occurred in the development of tourist function in rural areas. Special attention was paid to the so-called tourist communes (gmina), i.e. those where the tourist function is developed to at least an intermediate level. For these communes, nine functional types were identified, based on two features - the average length of visitors' stay and the percentage of all-year lodging). Moreover, changes taking place in the studied period were specified.

Keywords

Rural areas $\bullet$ tourist function $\cdot$ level of tourist function development

(C) University of Warsaw - Faculty of Geography and Regional Studies

\author{
Małgorzata Durydiwka \\ Institute of Socio-Economic Geography and \\ Spatial Management \\ Faculty of Geography and Regional Studies \\ University of Warsaw \\ e-mail:mdurydiw@uw.edu.pl \\ Received: 23 April 2013 \\ Accepted: 22 July 2013
}

Introduction

Analysing the tourist function of spatial units is one of the most common research topics in Polish tourism geography (Kurek, Mika 2007; Włodarczyk 2009). Tourist function is understood here as a socioeconomic activity pursued by a given area and its inhabitants, aimed at tourist services. The scale and nature of the tourist function can be presented by means of various measures and numerous qualitative features. In the literature, the development of tourist function is usually determined by measures based on the size of accommodation (e.g. Wyss 2003; Hagarty, Przezbórska 2005; Villarino Pérez et al. 2009), tourist traffic (e.g. Yagüe Parales 2002; Vágner 2003), the number of employees in tourist services or income from tourism (e.g. Piriou 1987; Swianiewicz 1989; Reid 1998) 1.

Rural areas boast special potential in the development of tourist function. According to J. Sikorska-Wolak (2005), there are many characteristics which are conducive to the development of this function in Polish rural areas, such as: diverse landscape preserved in its natural state, great stretches of forest and water basin areas, large legally protected areas, rich cultural heritage, untapped lodging opportunities and holiday traditions.

The purpose of this paper is to show the diversity in the level to which rural areas in Poland are developed in terms of their tourist function and to present the changes which took place in the period 1995-2005. The rural areas were identified based on the administrative divisions of Poland, thus the major research 'More on this subject in a paper by M. Durydiwka (2012) unit was a rural commune or a rural area separated from urbanrural communes. The total number of spatial units studied is 2168.

Methods for defining tourist function

Whether a tourist function appears in a given area depends on its tourist values and social demand for recreation and various forms of active tourism. Its existence is evidenced by tourist traffic usually accompanied by the development of tourist infrastructure (Fischbach 1989; Derek 2008; Włodarczyk 2009). Therefore, in order to define tourist function, two features (empirical measures) were chosen. The first characterises tourist traffic - the number of tourists using lodging facilities. This is the most important evidential feature for the existence of the tourist function in a given area. The second feature - the number of companies registered in the REGON system, section $\mathrm{H}^{2}$ - concerns the local community's economic activity in tourism, and thus the development of tourist services.

In order to quantify tourist function, a synthetic measure $\left(F_{t}\right)$ was employed according to the procedure of Z. Zioło (1973):

\footnotetext{
Section $\mathrm{H}$ covers: 1) renting lodging facilities designed for short-term stay with or without board - a service provided by: hotels, motels, hostels, camp sites, bed and breakfasts, guest houses, farms, holiday homes, dormitories, student residence halls and other unclassified units; 2) gastronomic activity pursued by restaurants, bars, canteens, and other units which specialise in catering for external customers, excluding sales from vending machines (http://www.stat.gov.pl/klasyfikacje/pkd 07/pdf/4 PKDklucz_2004-2007.pdf, 29 April 2013).
} 
MISCELLANEA GEOGRAPHICA - REGIONAL STUDIES ON DEVELOPMENT

Vol. 17 • No. 3 • 2013 • pp. 5-11 • ISSN: 2084-6118 • DOI: 10.2478/v10288-012-0041-2

$$
F_{t}=\frac{\sum_{j=1}^{m} x_{k j}^{\prime}}{m}
$$

where:

$x_{k j}$ - normalised $j$ empirical measure of $k$ spatial unit,

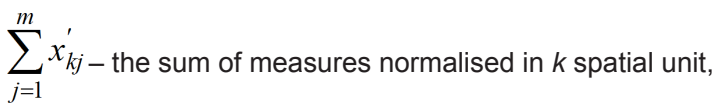

$m$ - number of normalised measures.

To ensure proper execution of further statistical procedures, all empirical measures had to be normalised. This was done by specifying the percentage of analysed measures in individual spatial units. The procedure used was thus based on quotient transformation.

Based on the value of the synthetic measure $F_{t}$, five levels (classes) of tourist function development in rural areas were specified. It must be noted that, in defining the class range, values of the arithmetic mean $(\bar{x})$ and standard deviation $(S D)$ were taken into consideration. Communes where the phenomenon is absent $\left(F_{t}=0\right)$ - in other words, where the tourist function is not developed - were defined as communes with zero tourist function development. The limits of further classes were defined as follows:

- the first level of tourist function development - from 0 to $x$;

- the second level of tourist function development - from $\bar{x}$ to $(\bar{x}+S D)$;

- the third level of tourist function development - from

$(\bar{x}+S D)$ to $(\bar{x}+2 S D)$;

- the fourth level of tourist function development - above $(\bar{x}+2 S D)$.

Diversity in tourist function development in rural areas in the period 1995-2005

Applying the synthetic measure of tourist function development $\left(F_{t}\right)$, five development levels were specified. Level 0 covers those communes where the tourist function was not developed $\left(F_{t}=0\right)$. In the period 1995-2005 the number of such communes decreased significantly - from 128 to 42 , meaning that their percentage in relation to the remaining communes under study dropped from $5.90 \%$ do $1.49 \%$. Level 1 indicates poorly-developed tourist function. This range comprises communes where the value of $F_{t}$ fluctuates between 0.000 and 0.046 at both the start and end of

\section{5}

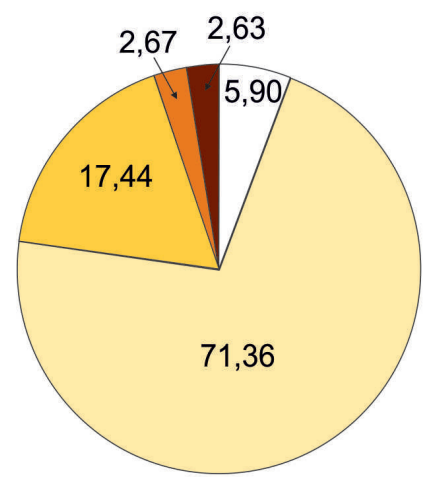

the study period. Quite contrary to the pattern above, the number of such areas increased significantly. In 1995 there were 1547 level 1 communes (i.e. $71.36 \%$ ), and in 2005, 1650 communes (76.11\%). Level 2, representing intermediate development of tourist function, comprises communes where the value of $F_{t}$ fluctuates between 0.046 and 0.165 in 1995, and between 0.046 and 0.174 in 2005 . The number of communes belonging to this class remained largely unchanged. In 1995 there were 378 level 2 communes $(17.44 \%)$, and in 2005,380 communes (17.53\%). In the next two classes, representing well-developed (level 3) and very well-developed (level 4) tourist functions, the number of communes decreased. In 1995, communes with a well-developed tourist function (level 3 ) were characterised by the index $F_{t}$ fluctuating between 0.165 and 0.285 . Their share in the total number of communes under study was $2.67 \%$ (58 communes). In 2005 , there were 50 communes $(2.31 \%)$ with a well-developed tourist function. However, for those communes the index $F_{t}$ had a higher value than in 1995 - it fluctuated between 0.174 and 0.302 . The best-developed tourist function was to be found in communes where $F_{t}$ was above 0.285 in 1995 and above 0.302 in 2005. There were 57 such communes $(2.63 \%)$ in 1995 , and $46(2.12 \%)$ in 2005.

Across Poland, in the period 1995-2005, a fairly steady level of tourist function development in rural areas occurred, with some polarising tendencies. It was observed that the number of communes with no developed tourist function (level 0) decreased threefold. However, at the same time, the number of communes with a well-developed tourist function (level 3) and a very welldeveloped tourist function (level 4) decreased, although not so significantly. Moreover, the number of communes with poorlydeveloped tourist function (level 1) increased markedly, that is by 103.

The spatial picture of the tourist function development in rural areas in the period 1995-2005 also appears relatively stable. In both years under study a significant role was played by communes in Pojezierze Mazurskie (the Mazurian Lake District), Pojezierze Kaszubskie (the Kashubian Lake District) and Bory Tucholskie (the Tuchola Forest District), Ziemia Lubuska (the Lubuskie Lake District) and Pojezierze Wielkopolskie (the Greater Poland Lake District) (fig. 2). In 2005, the tourist function of seaside communes strengthened, which resulted in the tourist function development units shifting from level 1 to level 2, e.g. in Kosakowo and Będzino, or from level 2 to level 3 or 4 , e.g. in Puck and Wicko. These phenomena corroborate somewhat A. Szwichtenberg's research findings $(1995,2006)$, according to which tourism is now perceived

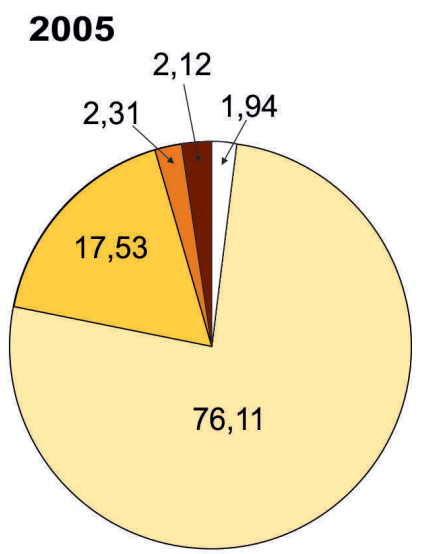

Level of tourist function development

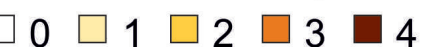

Fig. 1. Communes classified according to the level of tourist function development (\%) Source: Durydiwka (2012, p. 204). 


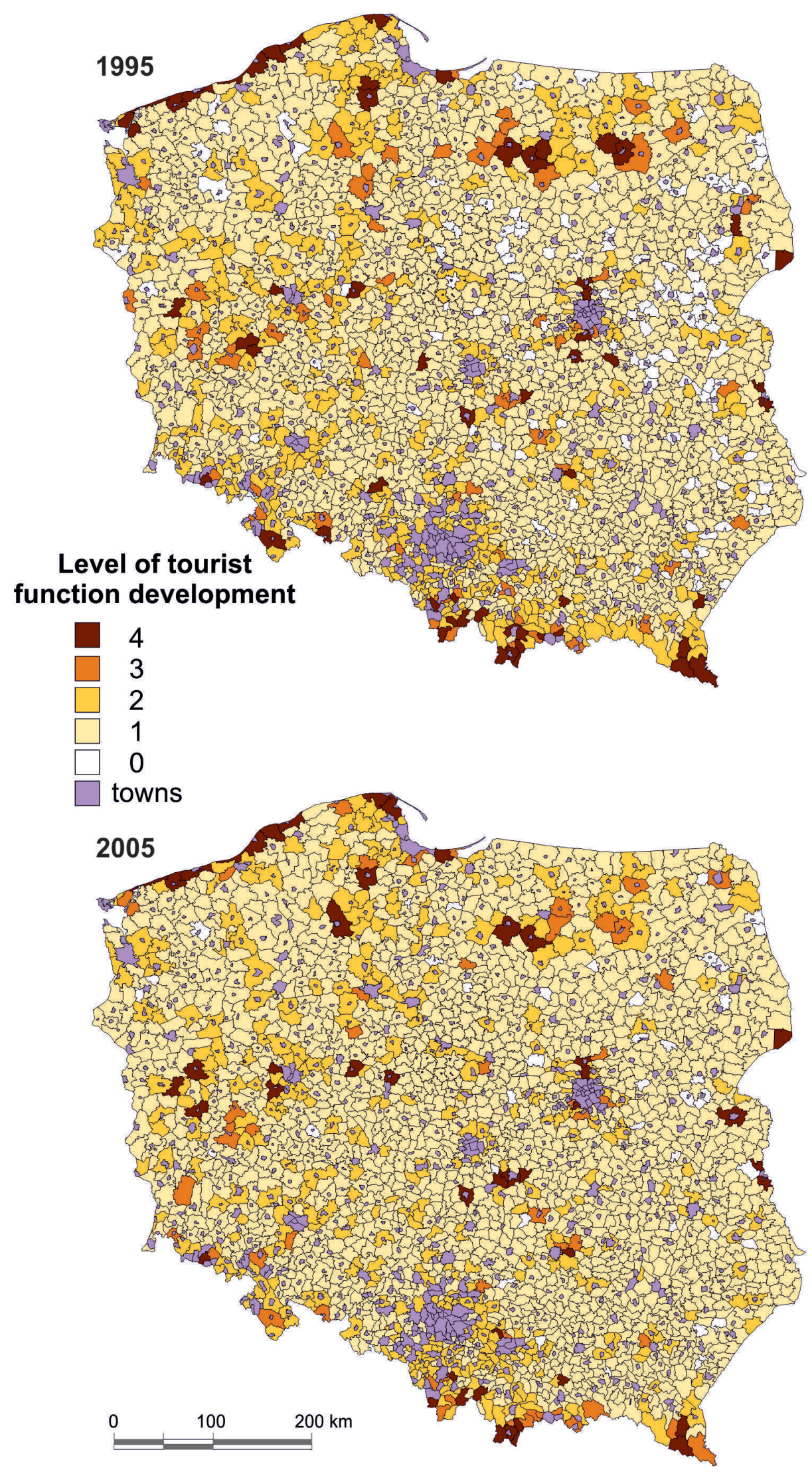

Fig. 2. Levels of tourist function development in rural areas of Poland (levels designated as in the text) Source: elaboration based on Durydiwka (2012, pp. 208-209). 
as the most important economic function in all seaside communes; in contrast, in 1994, local authorities from only half of seaside communes in Wybrzeże Środkowe (Middle Pomerania) were convinced that tourism was the most important economic function. Slightly different changes occurred in communes located in the mountains. It was observed that the tourist function of the majority of communes in these rural areas weakened to a certain degree. Nevertheless, it must be noted that in 2005 these communes still stood out in terms of tourist function development when compared to other regions in the country. A similar situation can be observed in the lake districts. This means that, in traditional tourist regions of Poland, the tourist function - although weakened when compared to 1995 - is still clearly observable. In both years under study, rural areas located at the seaside, in the Carpathian Mountains, the Sudetes, the Mazurian and Kashubian communes were significantly present on the tourism map.

The tourist function also weakened (as compared to 1995) in communes situated near big cities (e.g. Warsaw, Łódź, Kraków, the Upper Silesia conurbation, Białystok, and to some extent Poznań, Wrocław and Szczecin). In the case of many communes, they usually moved from level 4,3 or 2 to a lower level (e.g. Piaseczno, Wilga, Żabia Wola and Teresin near Warsaw; Tuszyn

$1995 \mathrm{r}$.

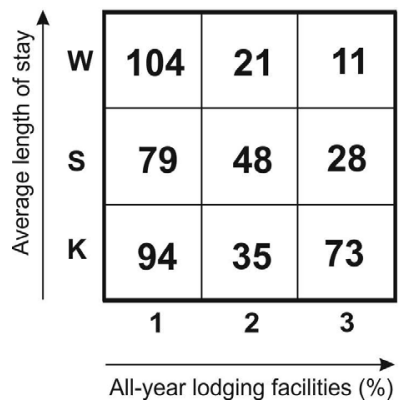

and Ozorków near Łódź; Niepołomice, Liszki and Myślenice near Kraków; Janów, Poraj and Kuźnia Raciborska in Upper Silesia, and Juchnowiec Dolny and Supraśl near Białystok). This is connected to the development of other economic functions. Generally, the expansion of various service functions, such as large-scale retailing or warehousing, is to be noted. Moreover, vacation properties (also called holiday homes or second homes) are more and more often transformed into permanent accommodation facilities.

In this paper - with reference to the concept of tourist space types according to S. Liszewski (1995) - communes with a tourist function developed to at least an intermediate level, (i.e. both in 1995 and 2005 the synthetic measure of tourist function level $F_{t}>$ 0.046 ) were described as tourist communes. Generally, despite the fluctuations in the level of tourist function development in rural areas observed in recent years, a relatively steady picture of the spatial diversity of tourist function can be observed. In both years under study, communes at the seaside, in the lake districts and in the mountains boast the best-developed tourist functions (as compared to all rural areas in Poland), and most of them can be described as tourist communes. Additionally, when looking at the distribution of tourist communes on the map of Poland, individual communes or

2005 r.

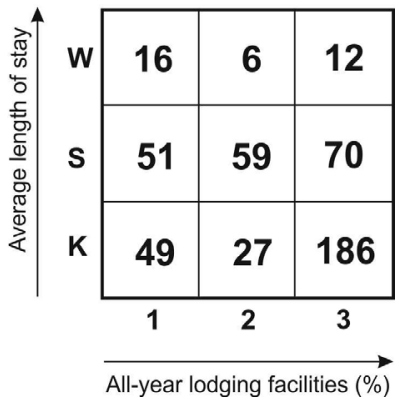

Fig. 3. Typological matrices for tourist rural areas (communes) (designation - as in table 1) Source: Durydiwka (2012, p. 239).

Table 1. Criteria for classifying tourist communes in terms of their functional types

\begin{tabular}{|c|c|c|c|}
\hline \multirow[b]{2}{*}{ Type } & \multirow[b]{2}{*}{ Name } & \multicolumn{2}{|c|}{ Values of features: } \\
\hline & & Average length of stay & $\begin{array}{c}\text { All-year lodging } \\
\text { facilities (\%) }\end{array}$ \\
\hline W1 & $\begin{array}{l}\text { Area with the function of holiday tourism, predominantly used } \\
\text { seasonally }\end{array}$ & 8 days and over & up to $25 \%$ \\
\hline W2 & $\begin{array}{l}\text { Area with the function of holiday tourism, partially used all } \\
\text { year }\end{array}$ & 8 days and over & from 25 to $75 \%$ \\
\hline W3 & $\begin{array}{l}\begin{array}{l}\text { Area with the function of holiday tourism, predominantly used } \\
\text { all year }\end{array} \\
\text { ( }\end{array}$ & 8 days and over & over $75 \%$ \\
\hline S1 & $\begin{array}{l}\text { Area with the function of tourism for medium-term stay, } \\
\text { predominantly used seasonally }\end{array}$ & 4-7 days & up to $25 \%$ \\
\hline S2 & $\begin{array}{l}\text { Area with the function of tourism for medium-term stay, partially } \\
\text { used all year }\end{array}$ & 4-7 days & from 25 to $75 \%$ \\
\hline S3 & $\begin{array}{l}\text { Area with the function of tourism for medium-term stay, } \\
\text { predominantly used all year }\end{array}$ & 4-7 days & over $75 \%$ \\
\hline $\mathrm{K} 1$ & $\begin{array}{l}\text { Area with the function of active, short stay, predominantly } \\
\text { used seasonally }\end{array}$ & 1-3 days & up to $25 \%$ \\
\hline K2 & $\begin{array}{l}\text { Area with the function of active, short stay, partially used all } \\
\text { year }\end{array}$ & $1-3$ days & from 25 to $75 \%$ \\
\hline K3 & $\begin{array}{l}\text { Area with the function of active, short stay, predominantly } \\
\text { used all year }\end{array}$ & 1-3 days & over $75 \%$ \\
\hline
\end{tabular}

Source: Durydiwka (2012, p. 233). 

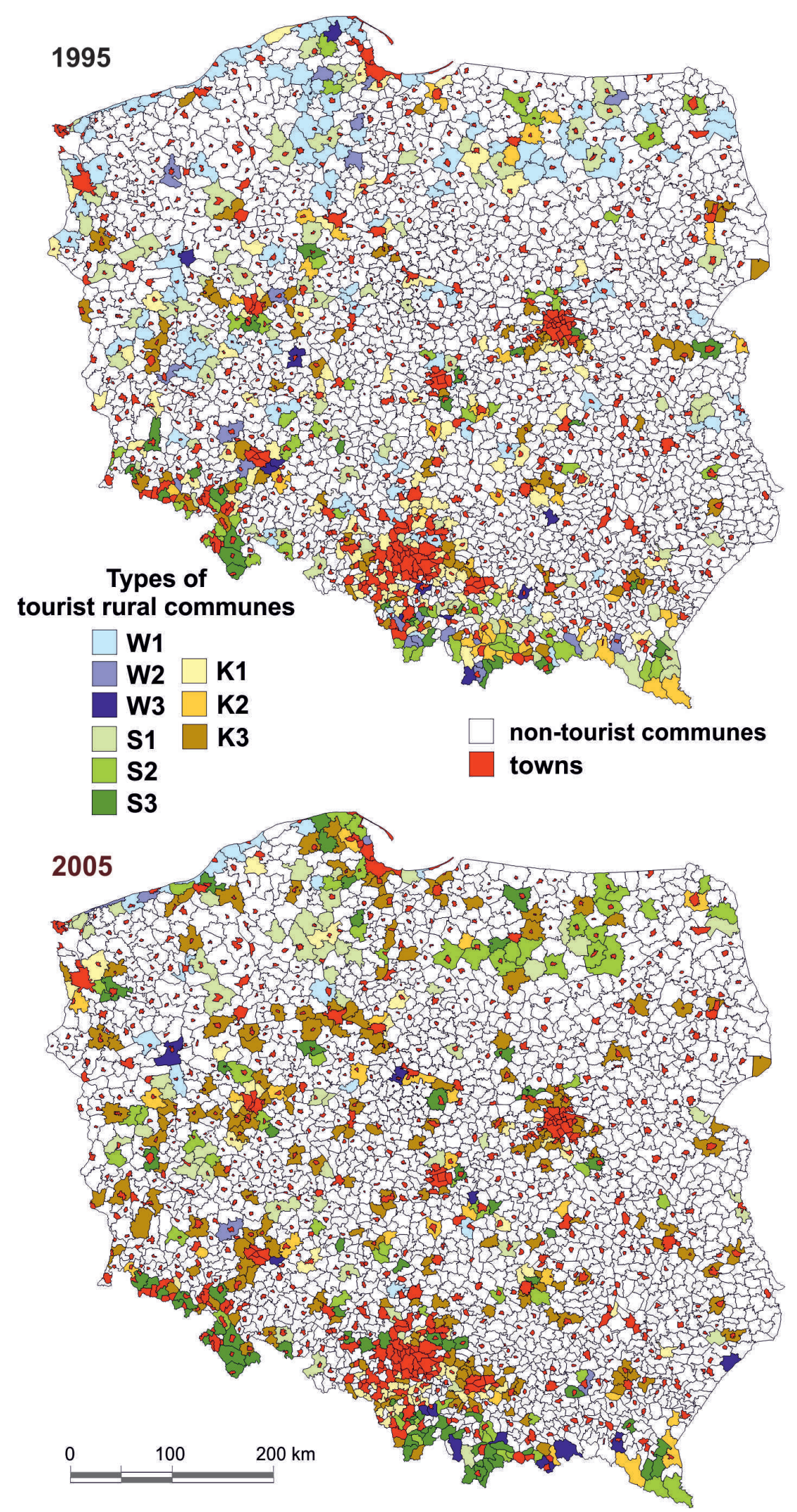

Fig. 4. Types of tourist communes classified according to the length of tourist stay and share of all-year lodging facilities in the period 1995-2005 (designation - as in table

Source: elaboration based on Durydiwka (2012, pp. 240-241). 
small clusters of communes in the central and eastern parts of the country are noticeable. This phenomenon appeared both in 1995 and 2005. The communes in question are: Białowieża, Włodawa, Bełchatów, communes located over the Pilica river (Inowłódz, Tomaszów Mazowiecki, Wolbórz, Sulejów), and communes in the Świętokrzyskie Province (Masłów, Górno, Bodzentyn, Daleszyce, Szydłów, Staszów). Other communes significantly visible in terms of their tourist function are those located near big cities: Warsaw, Poznań, Łódź, Kraków, Wrocław and the Upper Silesia conurbation (including communes located in the Kraków-Częstochowa Upland), as well as near Szczecin, Bydgoszcz and Toruń.

It may thus be argued that the tourist function in rural areas is developed and strengthened in the first place in regions that are highly attractive in terms of natural environment. This is corroborated by the research findings of R. Wilus (1997), S. Iwicki (2005), J. Wojciechowska (2009), M. Durydiwka (2009) and K. Szpara (2011). However, there are also factors modifying the development of tourist function in rural areas. These include above all the distance to large urban agglomerations and the presence of protected areas (especially national parks). Cultural values have a slightly lower impact on the development of tourist function. Nevertheless, these should not be underestimated. In some communes it was the cultural attractions that contributed significantly to the strengthening of tourist function or even its development. After all, it is becoming a commonplace practice to create new, increasingly sophisticated facilities of interest, aimed at boosting the attractiveness of a given commune, which thus becomes more competitive in the tourist market. It may be assumed - referring to the views held by A. Stasiak (2011) - that an important factor affecting the development of tourist function in rural areas is also the emergence of new tourist spaces, understood as areas which have just recently become available to tourists. Expanding tourist space in rural areas may occur due to tourists penetrating areas which earlier did not seem interesting or which were specially designed for tourist purposes. Examples of such practices may be: cemeteries (e.g. the First World War cemeteries in the Low Beskid, the Tatar cemeteries in Podlasie), new sites of religious interest (e.g. the sanctuary in Licheń Stary), extreme adventure sites (e.g. in Kashubia), zones of military operations from different historical periods (e.g. the Grunwald battlefield, the so-called Molotov line - including the Osowiec, Zambrów and Brest fortified regions), theme parks (e.g. JuraPark in Bałtów, Western Land in Sońsk), as well as media-related areas, i.e. those which serve as settings for films and serials (e.g. the open-air Soplicowo Museum in Cichowo, or Jeruzal, where the Polish serial Ranczo is filmed) and areas connected with folk tradition and culture (e.g. the Folk Handicraft Route in Podlasie, passing through Czarna Wieś Kościelna, Zamczysk and Janów).

\section{Functional types of tourist communes}

As mentioned earlier, communes where the tourist function is developed to at least an intermediate level (i.e. in both 1995 and 2005 the synthetic measure of the tourist function $F_{t}>0.046$ ) were defined as tourist communes. In the period 1995-2005 the number of tourist communes slightly decreased - from 493 to 476 . Much more significant changes occurred in functional terms.

The functional diversity of tourist communes was explained by means of the following features: average length of stay in a given area (which indirectly gives an insight into the purpose of stay) and seasonality of lodging facilities (which presents how long in a year a given area is used as a place of tourist interest). Consequently, nine types of tourist communes in rural areas were defined (table 1).

In the period under study the areas occupied by type $\mathrm{W}$ communes (rural areas for holiday tourism) decreased fourfold, from 136 in 1995 to 34 in 2005. However, the number of communes functioning as places for shorter stay, e.g. weekend stay (type K), increased - from 202 communes in 1995 to 262 in 2005. This is simply a reflection of a behavioural pattern, not exclusive to Polish society - the shortening of holidays. Research conducted by the author (Durydiwka 2012) proved that in the period under study the length of stay for tourist purposes in rural areas decreased from 6.4 to 4.7 days. Of course, shorter holidays and less frequent journeys do not only concern tourism in rural areas. In the period 1996-2005 the average length of tourist stay - measured by the number of nights spent in lodging facilities - decreased from 9.3 to 9.0 for longterm stays, and increased from 1.6 to 1.8 for short-term stays (taciak 2002, 2006)

These changes also affected the seasonality of tourist use of rural areas, as proved by a significant decrease in the number of communes where the share of all-year lodging was lower $25 \%$ (type 1) and an increase in the number of communes where the share of all-year lodging was above $75 \%$ (type 3). In the period 1995-2005 the number of type 1 communes fell from 277 to 116 , whereas the number of type 3 communes rose from 112 to 268 .

The functional changes that occurred in tourist communes were not only quantitative but also spatial in nature. An important feature of type $\mathrm{W}$ communes is the fact that they are directly connected to areas characterised by a high quality of natural environment, and located at significant distances from the largest urban agglomerations (Fig. 4). This trend was especially noticeable in 1995. Practically all of the communes situated at the seaside and in the lake districts were type $\mathrm{W}$ communes. They were used to a considerable degree only in summer (type 1). In 2005 most type W communes were located on the coast of the Baltic Sea. These communes were characterised by predominant or partial all-year use (type 1 and type 2). Only a few type W communes were characterised by all-year use (these were: Uście Gorlickie, Muszyna, Rymanów, Horyniec, Brześć Kujawski, Drezdenko, and Ujazd).

In the period under study, a significant number of communes with the function of holiday tourism (type $\mathrm{W}$ ) transformed into areas of type $\mathrm{S}$ (medium-term stay). To a considerable extent this change affected communes in the lake districts. Moreover, quite a significant number of these communes - especially those located in the Mazurian Lake District - changed from type 1 (predominantly seasonal use) to type 2 (partial all-year use). Communes of type K (short-term stay) are mainly situated near big cities (e.g. Warsaw, Kraków, Poznań, Bydgoszcz, Toruń, and Wrockaw). They are used for tourist purposes all year round (type 3). In fact, in the period 1995-2005, a strengthening of these functional types of communes located around big cities was to be observed.

\section{Summary}

The level of tourist function development in rural areas of Poland appears to be relatively steady. Rural areas with the tourist function developed to at least an intermediate level (so-called tourist communes) are clearly correlated with areas of high tourist value, especially in terms of natural environment. It may be thus argued that the development of tourist function depends to a great extent on the resources of the natural environment and to a lesser extent on the cultural resources. The development of tourist function in rural areas was also greatly conditioned by population growth in cities and strong administrative and socioeconomic links between rural areas surrounding urban units. Consequently, tourist function was developed in many rural areas located near large agglomerations. It must also be emphasised that the communes under study showed significant functional changes. The most important change concerns a 2.5-fold increase in the number of communes used for tourist purposes all year. This, in consequence, has improved the socioeconomic situation of the communes in question. 
Central Statistical Office. Available from: <http://www.stat.gov.pl/ klasyfikacje/pkd_07/pdf/4_PKD-klucz_2004-2007.pdf>. [29 April 2013].

Derek, M 2008, Funkcja turystyczna jako czynnik rozwoju lokalnego w Polsce, Uniwersytet Warszawski, Wydział Geografii i Studiów Regionalnych, Warszawa (doctoral thesis script).

Durydiwka, M 2009, 'Tourism classification of rural areas in Pomeranian region' in Global Changes: Their Regional and Local Aspects, ed W Wilk, University of Warsaw, Faculty of Geography and Regional Studies, Warsaw, pp. 196-202.

Durydiwka, M 2012, Czynniki rozwoju i zróżnicowanie funkcji turystycznej na obszarach wiejskich w Polsce, Uniwersytet Warszawski, Wydział Geografii i Studiów Regionalnych, Warszawa.

Fischbach, J 1989, 'Funkcja turystyczna jednostek przestrzennych i program jej badania', Acta Universitatis Lodziensis, Turyzm, vol. 5, pp. 7-26.

Hegarty, C, Przezbórska, L 2005, 'Rural and Agri-Tourism as a Tool for Reorganising Rural Areas in Old and New Member States - a Comparison Study of Ireland and Poland', International Journal of Tourism Research, vol. 7, pp. 63-77.

Iwicki, S 2005, 'Rozmieszczenie bazy agroturystycznej w województwie kujawsko-pomorskim i jej uwarunkowania' in Uwarunkowania rozwoju turystyki związanej z obszarami wiejskimi, eds B Sawicki, J Bergier, Wydawnictwo PWSZ im. Papieża Jana Pawła II, Biała Podlaska, pp. 62-66.

Kurek, W, Mika M 2007, 'Turystyka jako przedmiot badań naukowych' in Turystyka, ed W Kurek, Wydawnictwo Naukowe PWN, Warszawa, pp. 11-49.

Liszewski, S 1995, 'Przestrzeń turystyczna', Turyzm, vol. 5, no. 2, pp. 87-103.

Łaciak, J 2002, Uczestnictwo Polaków w wyjazdach turystycznych w 2001 roku, Instytut Turystyki, Warszawa.

Łaciak, J 2006, Uczestnictwo Polaków w wyjazdach turystycznych w 2005 roku, Instytut Turystyki, Warszawa.

Piriou, N 1987, 'La sédentarisation des caravanes dans le Finistère', Norois, vol. 34, pp. 141-152.

Reid, D G 1998, 'Rural tourism development: Canadian provincial issues', in Tourism and Recreation in Rural Areas, eds R Butler, C M Hall, J Jenkins, John Wiley \& Sons, ChichesterNew York-Weinheim-Brisbane-Singapore-Toronto, pp. 6980.

Sikorska-Wolak, J 2005, 'Rola turystyki w zrównoważonym rozwoju obszarów wiejskich' in Uwarunkowania rozwoju turystyki związanej z obszarami wiejskimi, eds B Sawicki, J Bergier, Wydawnictwo PWSZ im. Papieża Jana Pawła II, Biała Podlaska, pp. 72-78.
Stasiak, A 2011, Współczesna przestrzeń turystyczna' in Przestrzeń turystyczna - czynniki, różnorodność, zmiany, eds M Durydiwka, K Duda-Gromada, Uniwersytet Warszawski, Wydział Geografii i Studiów Regionalnych, Warszawa, pp. 39-51.

Swianiewicz, P 1989, 'Sytuacja finansowa miast i gmin turystycznych', Biuletyn Informacyjny Instytutu Turystyki, no 2(88), pp. 2-8.

Szpara, K 2011, 'Agroturystyka w Karpatach Polskich', Prace Geograficzne, no. 125, pp. 161-178.

Szwichtenberg, A 1995, Gospodarka turystyczna w okresie przejściowym, Wydawnictwo WSI, Koszalin.

Szwichtenberg, A 2006, Gospodarka turystyczna polskiego wybrzeża, Wydawnictwo Uczelniane Politechniki Koszalińskiej, Koszalin.

Vágner, J 2003, 'Regional differentiation of tourist and recreational function in Czechia' Acta Universitatis Carolinae, Geographica, vol. XXXVIII, no 1, Univerzita Karlova v Praze, Praha, pp. 475-482.

Villarino Pérez, M, de Uña Álvarez, E, Cánoves Valiente, G 2009, Reflexiones sobre experirncias de diversificación del turismo rural en Enpaña' in El turismo rural, ed J Sancho Comíns, Serie Geográfica, no 15, Universidad de Alcalá, pp. 67-78.

Wiluś, R 1997, Rozwój funkcji turystycznej w dolinie rzeki Warty na odcinku od Działoszyna do Uniejowa, Łódzkie Towarzystwo Naukowe, Łódź.

Włodarczyk, B 2009, Przestrzeń turystyczna. Istota, koncepcje, determinanty rozwoju, Wydawnictwo Uniwersytetu Łódzkiego, Łódź.

Wojciechowska, J 2009, Procesy i uwarunkowania rozwoju agroturystyki w Polsce, Wydawnictwo Uniwersytetu Łódzkiego, Łódź.

Wyss, F 2003, Basic introductory report: analysis of rural tourism' in the Americas, in El turismo rural en las Américas y su contribución a la creación de empleo y a la conservación del patrimonio, World Tourism Organization, Asunción (Paraguay), pp. 69-115.

Yagüe Parales, R M 2002, Rural Tourism in Spain', Annals of Tourism Research, vol. 29, no 4, 1101-1110.

Zioło, Z 1973, 'Analiza struktury przestrzennej i form koncentracji przemysłu województwa rzeszowskiego w świetle wybranych mierników', Folia Geographica, Series Geographica-Oeconomica, vol. 6, pp. 95-116. 